\author{
Lech Wołowski \\ The Pontifical University of John Paul II in Cracow \\ ORCID: 0000-0003-2012-1267
}

\title{
Mariological Interpretation of the Eight Beatitudes (Matt 5:3-10) ${ }^{1}$
}

\begin{abstract}
The article examines the question of the Mariological interpretation of the eight beatitudes contained in Matt 5:3-10. Christian theologians of all ages, from Clement of Alexandria to the authors of contemporary biblical commentaries, have proposed various interpretations of this biblical text. Among the multitude of interpretations developed throughout history, the Mariological aspect appears quite rarely. Yet, as Pope Benedict XVI observes, the very biblical Marian title "Blessed" should direct the theological thought to the Mariological aspects of this issue. In modern times, a very deep reflection on the subject was conducted by two great theologians of the XX century, J. Ratzinger (Benedict XVI) and H.U. von Balthasar. On the Polish ground, the task was partly undertaken by J. Tischner, who elaborated the theme of eight beatitudes in the key of the Marian pilgrimage of the nation. The present work is meant to deepen the Mariological-biblical analysis of the eight beatitudes and revive the discussion regarding this subject in the perspective proposed by Benedict XVI, to understand the beatitudes as a program of life for a modern Christian.
\end{abstract}

Keywords: eight beatitudes, Mariology, pilgrimage, Benedict XVI (Joseph Ratzinger), Hans Urs von Balthasar, Józef Tischner

\section{Introduction}

The aim of this work is to present the Mariological interpretation
of the eight beatitudes of the Gospel according to St. Matthew.

${ }^{1}$ This article is a revised version the study published originally in Polish: Lech Wołowski, "Mariologia ośmiu błogosławieństw (Mt 5,3-10)," Collectanea Theologica 90 (2020) no. 3, 79-121. Translated from Polish by Maciej Górnicki. 
Since this issue can be approached from different angles, it should be clarified at the beginning from which point of view the problem will be dealt with.

On the one hand, it may seem that sufficient grounds to address such a topic are missing. For not only in the eight beatitudes, but in the whole, even broadly taken, Sermon on the Mount, Jesus never mentions the name of Mary or in any way refers to her. Thus, if one only adheres to the biblical text considered here (in this case, Matt 5:3-10), understood even in the broader context of the Sermon on the Mount (Matt 5:1-7:29), one could conclude that there can be no Mariological interpretation of the eight beatitudes.

On the other hand, however, one can look at the problem more broadly, i.e., according to the principle of an integral interpretation of the Holy Scripture. In such a light, a proper understanding of this particular passage requires its being set in the entirety of Revelation. Benedict XVI is a great proponent of this approach, called the "canonical method." In his post-synodal exhortation Verbum Domini ${ }^{2}$ he presents the theoretical aspects of the application of this method within the Catholic biblical hermeneutics and the reasons why it has gained the support of the Magisterium of the Church. Consequently, in his monumental work Jesus of Nazareth, ${ }^{3}$ he showed how to apply this method in practice to reflections on a biblical text that are not strictly exegetical but dogmatic.

So, if we take this approach and look at the eight beatitudes as a "program of Christian life," there is no doubt that the person who

\footnotetext{
${ }^{2}$ Cf. Benedict XVI, Verbum Domini, 29-41. A detailed overview of methods of interpreting biblical texts and their applications in Mariology can be found in: B.A. Buby, Biblical Methodology.

${ }^{3}$ In the foreword to this work, the Pope refers to this method (see Benedict XVI, Jesus of Nazareth, part 1,11) and then shows how it can be applied in dogmatic analyses (from the point of view of the theme of the present work, the chapters on the Sermon on the Mount and the proclamation of the Gospel are central here; see Benedict XVI, Jesus of Nazareth, p. 1, 51-114). In the strictly Mariological field, an example of such Mariological interpretation of Biblical texts can be found in the encyclical of John Paul II Redemptoris Mater (especially 7-24, 35-41; cf. also Benedict XVI, Verbum Domini, 27-28).

${ }^{4}$ This is exactly how B.T. Viviano presents the beatitudes in the Catholic Biblical Commentary: "Matthew therefore transforms the brief messianic manifesto into
} 
implemented this program from the practical point of view in the fullest possible way (not necessarily in a formally conscious way) was the Blessed Virgin Mary - the first and greatest of the saints and the one whom Scripture calls "blessed." This truth was clearly formulated by Paul VI, who in his solemn address delivered on November 21, 1964 at the end of the Third Session of the Second Vatican Council, said:

The Mother of Jesus exemplified in her own life the beatitudes preached by her Son, and so the Church, in and through the many activities of its various members and vocations, rightly regards Mary, Mother of the Church, as the perfect model of the imitation of Christ. ${ }^{5}$

Benedict XVI also spoke about this in the meditation before the Angelus Domini on 30 January 2011, when he addressed the topic: The Beatitudes are a new program of life and encouraged the faithful present there in the following words: "Dear brothers and sisters, let us invoke the Virgin Mary, the Blessed par excellence, asking her for the strength to seek the Lord (cf. Zeph 2:3) and to follow him always, with joy, on the path of the Beatitudes."6

a life program.” B.T. Viviano, “The Gospel according to St. Matthew," 927 [Polish ed.]).

${ }^{5}$ Since this statement is sometimes translated very differently in literature, we quote the original version: "In hac mortali vita perfectam Christi discipuli formam expressit, speculum fuit omnium virtutum, atque plene in suos rettulit mores beatitudines illas, quae a Christo Iesu praedicatae fuerunt. Quo fit, ut Ecclesia universa, dum multiformem suam vitam actuosamque suam navitatem explicat, a Deipara Virgine absolutissimum exemplum sumat, quo perfecte Christum imitari oporteat." AAS 56 (1964), 1016.

${ }^{6}$ Benedict XVI, The Beatitudes. The Catechism of the Catholic Church speaks precisely in the same spirit: "The Beatitudes [...] shed light on the actions and attitudes characteristic of the Christian life; they are the paradoxical promises that sustain hope in the midst of tribulations; they proclaim the blessings and rewards already secured, however dimly, for Christ's disciples; they have begun in the lives of the Virgin Mary and all the saints" (CCC, 1717). As we can see, the figure of Mary appears quite often in the context of the eight beatitudes in the Church's Magisterium - both the statements of the popes and documents. However, this situation has not yet met an adequate response in a systematic theological reflection. The purpose of this work is to fill this gap. 
In the present paper, following the broader, i.e., canonical, approach to the problem discussed here, indicated by the Church's Magisterium, and without aspiring to a study of an exegetical character, we will undertake to present a contemporary dogmaticMariological analysis of the Biblical text of the eight Beatitudes in the light of the relevant Biblical Mariological texts. However, before we can get to the heart of the matter, the question why the problem posed here is topical and relevant to contemporary theology needs to be answered.

It is so for, at least, two reasons. The first concerns the benefits of this approach for Mariology itself. All too often Mariology has been, and still is, practised in isolation from biblical research. Reflecting on the Mariological aspects of the eight beatitudes satisfies all the demands that Józef Kudasiewicz made some time ago for the biblical renewal of Mariology: "It is therefore necessary to ponder in faith over God's plan of salvation, as established in Scripture, and to look for Marian traces in it; to ask what place she occupies in God's plans of salvation. ${ }^{7}$ In the same spirit, Charles Neumann, diagnosing the causes of the post-conciliar decline in interest in Mariology, postulated and predicted - citing the analyses of René Laurentin and Gérard Philips - that the most promising area for the development of Mariology in the future (and therefore at present) should be biblical theology. ${ }^{8}$

Secondly, this approach is very important for contemporary Christian anthropology. ${ }^{9}$ For, if we agree with Benedict XVI that the eight blessings set the agenda for Christian life, the direct conclusion from this assumption is that their Mariological interpretation is becoming a very important voice on the issue of the identity and place of the Christian in general, and of women in particular, in the contemporary Church and world. ${ }^{10}$

\footnotetext{
${ }^{7}$ J. Kudasiewicz, [statement in:] Biblijna droga, 16.

${ }^{8}$ Cf. C.W. Neumann, "The Decline of Interest," 26.

${ }^{9}$ This aspect has been repeatedly highlighted by R. Laurentin in his numerous works, whose contribution in this regard is summarised by: C.W. Neumann, "The Decline of Interest," 27-29.

${ }^{10}$ Of course, the Mariological and biblical discussion on the place of women in the Church and the world is nothing new. It was undertaken years ago (A. Feuillet,
} 
Another aspect of pastoral nature is worth noting. Peter Casarella in his work devoted to the analysis of the Apostolic Letter of John Paul II, Rosarium Virginis Mariae, in which the Pope introduces a new part, dedicated to the so-called luminous mysteries, to the Rosary meditations. He emphasizes the important role that the Rosary meditations should play in the process of new evangelization:

Using the Pope's favorite image of the apostles readying themselves to become fishers of men, the letter on the Rosary bids a final farewell to those preparing to go "out into the deep" (duc in altum) and meet the challenge of evangelization in the new millennium of Christianity (cf. Rosarium Virginis Mariae, 24). The Rosary can serve the agents of the new evangelization because it "is a compendium of the entire gospel" (Rosarium Virginis Mariae, 1$)^{11}$

Therefore, at the end of the paper, the thread of reflection on the third mystery of light, closely linked to the eight beatitudes through the issue of proclaiming the Kingdom of God, will be developed, as

Jésus et sa mère) and continued both internationally (B. Rinaldi, Madonna) and in Poland (W. Życiński, Matka, 137-159). However, it still lacks the necessary dynamics and direction. Hence the current proposal to revive it with a new thread, concerning the Mariology of the eight beatitudes. It is worth mentioning, however, that in recent years, Gloria Dodd has made an important contribution to this discussion. She has drawn the attention of researchers to the fundamental distinction between two currents for Mariology: feminism, referring to the revolutionary times of the 1960s and the new feminism based on the teachings of Paul VI and John Paul II (see: G.F. Dodd, "Feminist and New Feminist," 279-280). The author makes an insightful analysis of both these approaches, pointing to significant differences in the view of the person of Mary representing both these currents and, consequently, the formation of two different visions of anthropology (cf. G.F. Dodd, "Feminist and New Feminist," 290-294). In the context of the distinction between the two currents, it is worth posing a question: if John Paul II's call for a new evangelisation has met with such a lively response all over the world, why has his call for a new feminism (contained in the encyclical Evangelium Vitae, 99) been practically unnoticed? If Mary is so often referred to as the "Stars of the new evangelisation," it seems that her role as 'Stars of the new feminism' should also attract the attention of researchers."

${ }^{11}$ P. Casarella, "Contemplating Christ," 163. 
a summary and at the same time as an application of the results of the study. ${ }^{12}$

Last but not least, a final issue. As Scott Hahn rightly points out, in today's ubiquitous specialisation, a Mariological view on biblical issues allows theologians to get out of the narrow provinces of their narrow fields of interest and into the wide waters of the universalism of the Church. Referring to Jacques Barzun's diagnosis of a progressive "disease of specialism" in science, ${ }^{13}$ Hahn shares the following observation with the reader, which also fits well with the character of this work:

Barzun complains that, today, "The expert takes a little subject for his province - and remains provincial all his life" [...] Yet, somehow, out there in our provinces, something else led us, or drew us, to Miryam of Nazareth - a woman of the provinces. And, in meeting her, a whole world opened up to our eyes. For, in her, more than almost any other human subject, the provincial becomes universal. [...]. Perhaps it is because Mary is the very archetype of motherhood, and it is every mother's job to gather her scattered children. [...] For this reason and many others, I believe that Mariology, perhaps more than any other field, can provide an antidote to the theological strains of Barzun's Syndrome - [...] can gather the scattered disciplines by modeling an integrative, holistic approach. ${ }^{14}$

${ }^{12}$ P. Casarella often refers in his work to the motif of the "school of Mary" in which the pupils of Christ are educated (see: P. Casarella, "Contemplating Christ," 163-172). An important example of the application of the considerations contained in this work may therefore be the question of the catechetical aspect of the "school of Mary described in Scripture and by Tradition," which was analysed by Piotr Tomasik, drawing attention, among other things, to the necessity of biblical embedding the Mariological issues undertaken in the catechesis (cf. P. Tomasik, "Catechesis of Mary," 159). The analyses contained in this article provide rich material, which, after appropriate adaptation, may serve as a basis for the preparation of a series of Marian catechesis/homilies meeting the criteria postulated in this study.

${ }^{13}$ See: J. Barzun, The Culture, 6-7.

${ }^{14}$ S. Hahn, ,Biblical Theology,” 9-10. 


\section{Status Quaestionis}

The theme of the eight beatitudes contained in Matthew 5:3-10 has inspired theologians since the first centuries of Christianity. Clement of Alexandria began the tradition of commenting on this famous biblical text in his Stromata. ${ }^{15}$ In the middle of the third century Origen also took up this issue in his extensive commentary on the Gospel according to St Matthew. Unfortunately, the first nine books of this commentary - probably devoted largely to the Sermon on the Mount - were lost. ${ }^{16}$ The first fully preserved and dedicated patristic work is the Homilies on the Beatitudes of Gregory of Nyssa. ${ }^{17}$ Shortly after Gregory, Augustine wrote his famous commentary on the eight beatitudes. ${ }^{18}$

Throughout the centuries, many Church Fathers, medieval scholastics, as well as contemporary commentators of the Scriptures have tried to penetrate this subject in their studies. Patristic reflection was usually deeply rooted in the Bible, but there were few Marian references in it in the area we are interested in. Although from the Middle Ages to the Renaissance, Marian devotion has truly

15 Clement subordinates the subject of blessings to the broader problem of martyrdom that he is considering. Starting from the physical aspects of martyrdom (hunger, poverty, suffering, sadness), he tries to put the main emphasis on the supernatural motivation to undertake these hardships (blessed are persecuted for justice). The blessings here are taking the path of asceticism and the gradual ascension of the soul to God (see: Clement of Alexandria, Stromata, vol. I, Kobierzec IV, pt. I: O Męczeństwie, p. b) O błogosławieństwach, 25-41).

${ }^{16}$ Cf. E. Stanula, Wprowadzenie, in: Orygenes, Komentarz do Ewangelii, 6.

${ }^{17}$ Gregory of Nyssa, Homilies on the Beatitudes. In this work, Gregory takes up the motif of the soul's ascension to God that Clement began, and proposes a scheme of understanding the eight blessings as individual levels, after which man, as if on a "Jacob's ladder," consistently climbs towards heaven, that is, towards true happiness, which Gregory understands as the participation of man in the life of God (see: Homily I, 33).

18 Augustine of Hippo, De sermone Domini in monte. In this commentary, Augustine made an original juxtaposition of the eight blessings (Matt 5:3-10) with the seven gifts of the Holy Spirit (cf. Is 11:1-2) and with the seven invocations of the Lord's prayer "Our Father" (Matt 6:9-13). The reader interested in a deeper analysis of this list is referred to S.T. Pinckaers, Komentarz św. Augustyna, 145-164. 
flourished, the biblical theme has definitely been dominated by a homiletical and devotional style. ${ }^{19}$

It is worth reflecting whether modern times have brought some balance in this regard. It is difficult to give an unequivocal answer. On the one hand, if we consider the beatitudes separately, we can attribute a contemporary Mariological monograph to almost every one of them. ${ }^{20}$ On the other hand, if we consider the eight blessings as an inseparable whole and take into account the contemporary biblical commentaries on this text, in the vast majority they will remain silent about the Mariological aspect. ${ }^{21}$

There are, however, studies that do not deal with an explicit Mariological interpretation of the eight beatitudes, but it can be read from them, at least partially. ${ }^{22}$ The biblical-Mariological research and studies by authors such as Aristide Serra, Stefano Manelli and Hugolin Langkammer are particularly valuable here. ${ }^{23}$

Due to the dogmatic nature of this paper, the work entitled: Mary in the Mystery of the Church [Maryja w tajemnicy Kościota], published jointly by two giants of contemporary theology, Hans Urs von Balthasar and Joseph Ratzinger, deserves special attention. Particularly interesting will be the reflection of Ratzinger (Benedict $\mathrm{XVI}$ ), who devotes a lot of space in his research to the titles of

\footnotetext{
${ }^{19}$ A short Mariological characteristics of this period can be found in: K. Kowalik, "Piąty dogmat?," 81-99. The homiletic and prayerful aspect of medieval Mariological creativity has been analysed in: N.M. Siwiński, "Rogamus te," 91-145.

${ }^{20}$ For example, the following work could be considered a monograph devoted to the Marian aspect of the First Blessing: Ł. Samiec, Maryja. The problem is that very often, when discussing this subject, commentators focus on different aspect of poverty, then the one to which this blessing actually points out.

${ }^{21}$ Also, just as an example, it is sufficient to note that in his contemporary commentary on the Gospel of St. Matthew Silvano Fausti, SJ mentions seven key aspects in the light of which, in his opinion, the discussed text can be read: Christological, theological, anthropological, soteriological, ecclesiological, eschatological and moral. As can be seen, there is no room here for a separate treatment of the Mariological aspect. (see: S. Fausti, Wspólnota czyta Ewangelię, 68).

22 Among such work it is worth mentioning: H. Rondet, Maria nel disegno; B. Häring, Pieśń stugi.

23 See: A.M. Serra, E c'era la Madre; S.M. Manelli, Mariologia biblica or S.M. Manelli, All generations and H. Langkammer, Maryja w Nowym Testamencie.
} 
"blessed" and "full of grace," which in turn indicate a special link between charitology, Mariology and the issue of beatitudes. Ratzinger has emphasized as central for charitology the Mariological aspect of the path to salvation that the Christian walks, which in this work will be interpreted as the Marian path of eight beatitudes:

A proper understanding of the meaning of the Divine sign in the birth of a Virgin indicates the place that devotion to the Blessed Virgin Mary occupies in theology, which can be derived from the faith of the New Testament. If we would like to indicate which theological treatise Mariology belongs to as its concretization, it would be the study of grace, which of course forms a whole with ecclesiology and anthropology. As the true "daughter of Zion" Mary is the image of the Church, the image of a believer who, only through the gift of love - by grace - can be saved and become himself. ${ }^{24}$

We cannot fail to mention Polish achievements. Although not in the context of the blessings themselves, but generally against the background of the New Testament, Feliks Gryglewicz took up the issue of Mary as "blessed." ${ }^{25}$ However, as far as the specific topic of the present work is concerned, the commentary (now almost completely forgotten) developed by Józef Tischner in the key of the nation's Marian pilgrimage deserves special attention. ${ }^{26}$ What is interesting is the fact that Tischner, who did not deal with the subject discussed here directly, let alone a Mariological commentary on eight beatitudes. He referred to the image of the pilgrimage, which, from an etymological point of view, fits this issue exceptionally well. ${ }^{27}$

${ }^{24}$ J. Ratzinger, Wprowadzenie $w$ chrześcijaństwo, 274, cf. also. J. Ratzinger, H.U. von Balthasar, Maryja w tajemnicy Kościoła, 53-60. As can be seen, the titles "blessed" and "full of grace" are supplemented by "daughter of Zion." All these titles will be important building blocks of our analysis.

${ }^{25}$ See: F. Gryglewicz, Błogosławiona.

${ }^{26}$ See: J. Tischner, Książeczka pielgrzyma.

${ }^{27}$ It is worth noting at this point that the equivalent of the Greek adjective macáriois used in the Greek Gospel is the Hebrew "ašrê" (see: B.T. Viviano, "Matthew's 
The combination of the motifs of pilgrimage, Mary and the eight beatitudes, proposed by Tischner, seems to have a timeless character and has become one of the main impulses to undertake the present research. The pilgrimage theme borrowed from Tischner, considered in the context of the eight beatitudes, is therefore not an original aspect, but nevertheless a very important feature of the present paper.

In terms of originality, another aspect will be more important. The blessings were described by the Catechism of the Catholic Church as "paradoxical promises." 28 If Mary had implemented these blessings in her life in an exemplary way, then she herself had to go through these paradoxes. They must emanate from various aspects of her life, they must be visible in the biblical texts that describe it.

One of the few reflections capturing such an aspect of paradoxicity in Mariology, worth mentioning, is the approach presented by Aaron Riches. Although this time also not directly in the context of the eight blessings, but in the context of the issue of the Immaculate Conception and the Annunciation, he saw the Mariological-Christological paradox of the so-called "reflexive circularity": her immaculate fiat is immersed in the preceding one, the eternal, kenotic "yes" that the Son of God says to the Father. The paradox consists in the fact that the realization of the Son's fiat, which precedes and enables the immaculate fiat of Mary, is itself conditioned by the Mary's fiat. ${ }^{29}$

It is precisely this aspect of paradoxicity that will be highlighted and emphasised in this work. For we can safely put forward the thesis that if we look at the problem of the eight beatitudes from a Mariological point of view, we are dealing with a similar phenomenon of "reflective circularity." Mary had already been realizing in her life the ideal of the eight blessings before Christ

Gospel," 926), whose core of meaning_-besides "to be happy"_includes such categories as "to flourish" and "to prosper," i.e., "to develop," "to move forward," "to make progress on the road" - all of this, of course, under God's blessing — and from here it is not far to "make a pilgrimage" (an etymological study of the meaning of 'ašrê / makárioi can be found in: I.J. Van der Merwe, "Biblical happiness," 697-704).

${ }^{28}$ CCC, 1717.

${ }^{29}$ See: A. Riches, "Deconstructing the linearity," 180. 
actually preached them during the Sermon on the Mount (it is not even known if she ever heard of them). The realisation of these blessings is a kenotic immersion in Christ, which-like His kenosis preceding everything - cannot abound in anything but paradoxes. ${ }^{30}$

The above mentioned authors, such as Balthasar, Ratzinger and Tischner are also sensitized to this aspect of Mariology, although not necessarily explicitly presented in the category of a paradox. Consequently, the following analyses will most often refer to these authors.

\section{"Blessed," "Happy" and "Full of Grace”}

We mentioned above that Ratzinger linked the theme of the eight blessings to the Mariological aspect through the biblical Marian title "blessed." 31 This association needs to be substantiated and clarified. In the translation of the Millennium Bible [Biblia Tysiaclecia] ${ }^{32}$ popular in Poland, the title "blessed" appears in various contexts in the New Testament, and in its original version it corresponds to various Greek terms, not always the same as the key term in this case

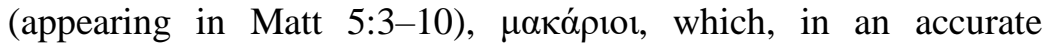
translation into Polish, should be translated using the term "happy." 33 In the most frequently recited biblical verse, in which

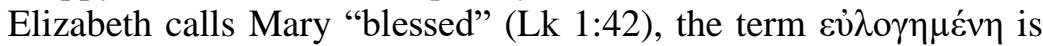
used. In linguistic terms, these terms fit together well. However, we temporarily lose sight of the link with $\mu \alpha \kappa \alpha$ ó

In order to regain this link, reference should be made to further verses in the same Elizabeth's speech. There, Mary is called

\footnotetext{
${ }^{30}$ Balthasar makes a similar observation: "If the life of the Son is shown as a deeper and deeper kenosis, the life of the Mother appears to be that of a faithful companion." (H.U. von Balthasar, Medytacja chrześcijańska, 58).

${ }^{31}$ A similar thing was done by Tischner, who wrote in his commentary: "She was the first to be called 'Blessed,' so the Blessings indirectly refer to her,' (J. Tischner, Ksiązeczka pielgrzyma, 49).

${ }^{32}$ Polish Bible quotations given after Biblia Tysiaclecia (5 ed). English quotations: RSV. When referring to the Greek original and interlinear translation, we use: Grecko-polski Nowy Testament, R. Popowski, M. Wojciechowski (transl.) (further on: GPNT).

${ }^{33}$ GPNT, 15.
} 


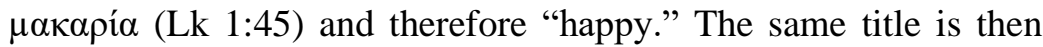
confirmed in the Magnificat hymn (Lk 1:48). ${ }^{34}$ Despite some inaccuracies in popular translations, there is no doubt that the Bible describes Mary using the same title as used in the eight beatitudes expressed in Matthew 5:3-10.

It is worth adding that the meeting of Mary and Elizabeth is not the only evangelical context in which Scripture bestows the title

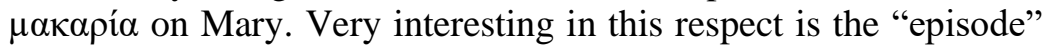
with the so-called anonymous woman from the crowd (Lk 11:27-28). The term that is applied to Mary in this fragment can be interpreted in a double sense. Firstly, in the context of her Divine Motherhood: "blessed is womb ( $\mu \alpha \kappa \alpha \rho i ́ \alpha \dot{\eta} \kappa o 1 \lambda i \alpha)$ that bore you and the breasts at which you nursed," secondly in the context of listening to and observing the Word of God: "Indeed, blessed ( $\mu \alpha \kappa \alpha$ ápı1) are those who hear the word of God and keep [it]." 35 What is particularly important is the second part in which, in a strictly Mariological context, the same word is spoken by Jesus Himself as the one $\mathrm{He}$ utters in the eight beatitudes.

Although not so direct, yet still essential relationship is there also between the Marian-charitological title "full of grace"

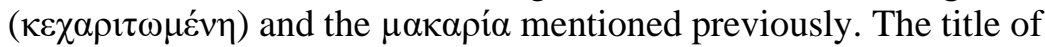
"full of grace" is introduced in the scene of the Annunciation

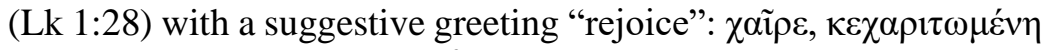
("rejoice, filled with grace"). ${ }^{36}$

We do not want to delve here into detailed etymological considerations. For the purposes of this work, it suffices to note that

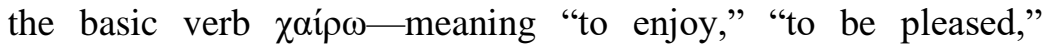
"to rejoice immensely" 37 and being a root of the nouns $\chi \alpha \rho \alpha$ and

\footnotetext{
${ }^{34}$ Concerning further exegetic details of the differences in Marian titles occurring in Lk 2:42 and Lk 2:45; see: B. Adamczewski, "Szczęśliwa, która uwierzyła," 75-87.

${ }^{35}$ Quotations after GPNT, 311. More on the interpretation mentioned here in: J. Kudasiewicz, [statement in:] Biblijna droga, 41-45; B. Adamczewski, "Szczęśliwa, która uwierzyła," 84-87 and L. Wołowski, "Słowo o syntezie," 254-263.

36 GPNT, 239.

${ }^{37}$ See: J. Strong, Grecko-polski stownik, 825.
} 


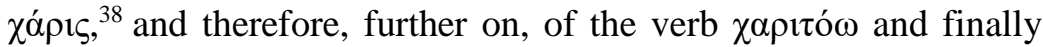
$\kappa \varepsilon \chi \alpha \rho i \tau \omega \mu \varepsilon \dot{v \eta},{ }^{39}$ which is discussed here-points to the deep-rooted element of joy in the semantic field of this title. ${ }^{40}$

The call for joy made to Mary by angel Gabriel in $\chi \alpha i \tilde{\rho} \varepsilon$, $\kappa \varepsilon \chi \alpha \rho i \tau \omega \mu \varepsilon \dot{v} \eta$ and the analogous call for joy ( $\chi \alpha i ́ p \varepsilon \tau \varepsilon)$ made in Matt 5:12 to those who are $\mu \alpha \kappa \alpha$ piol, becomes, under these circumstances, a direct link between the title of "full of grace"

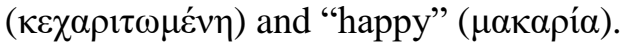

A multifaceted analysis of the title of "full of grace" in the Mariological-dogmatic aspect was conducted by Ratzinger. ${ }^{41}$

\section{Analysis of Individual Beatitudes in the Key of Contemporary Biblical and Mariological Reflection}

Below, we will reflect on the eight beatitudes, one by one, and propose their contemporary Mariological interpretation. Each time a series of Marian biblical texts will be considered, which will then be referred to the individual beatitude. Due to the dogmatic nature of the considerations contained here, these texts will be accompanied by a theological commentary - it will be confronted at times with the thought of contemporary biblical and Mariological academics, with special attention given to the thought of Ratzinger, Balthasar and Tischner.

\section{1. "Blessed are the poor in spirit" (Matt 5:3)}

The issue of poverty combines two points of view from which it is worth looking at this beatitude: the Marian aspect and the pilgrimage aspect.

The biblical texts in which it is best seen how Mary lives her poverty are closely related to her pilgrimages. There are many such

\footnotetext{
${ }^{38}$ Ibid., 827-828.

${ }^{39}$ Ibid., 829.

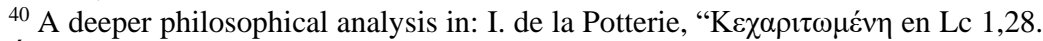
Étude philologique." It is also worth consulting: F. Rossier, "Kecharitomene (Lk. 1:28)."

${ }^{41}$ See: J. Ratzinger, H.U. von Balthasar, Maryja w tajemnicy Kościoła, 53-69.
} 
texts, for example: the mountain pilgrimage on the way to meet Elizabeth (Lk 1:39-40), the pilgrimage to the census in Bethlehem (Lk 2:1-7), the pilgrimage of the flight to Egypt (Matt 2:13-15), the annual pilgrimage to Jerusalem (Lk 2:41-51). Looking at the richness of these texts, one can conclude that the theme of Mary's poverty is very rich in meaning. For it is not just poverty in the sense of material deprivation, although this experience was not foreign to Mary, as the second of these texts clearly shows. There would be no lack of room in an inn for a wealthy person and she would not have to put the newborn child in a manger. However, it is not this aspect that will be the most important here.

Notwithstanding the exegetical hypotheses that Matthew added words about the spiritual nature of poverty, to which the first blessing refers, ${ }^{42}$ the biblical text of Matthew 5:3, which has taken this form (oi $\pi \tau \omega \chi 0 i ̀ \tilde{\omega} \pi v \varepsilon v ́ \mu \alpha \tau 1$ - "poor in spirit" ${ }^{43}$ ), clearly encourages not to reduce this kind of poverty to the issue of material deprivation alone. Exactly the same is the case with Mary's poverty: the problem is not (only) that she did not have suitable clothes for the Baby Jesus and a place to put it ( $\mathrm{Lk} 2: 7)$.

The spiritual dimension of poverty has been understood differently by commentators. In his reflections on this blessing, Aleksy Klawek suggests that it consisted in accepting the state of material poverty voluntarily. The spiritual aspect would therefore be limited here only to the fact that the addressees of this blessing: "'in spirit,' that is to say, by an act of will, consented to their position." 44

Serra goes much further in his analysis. He sees the equivalent of

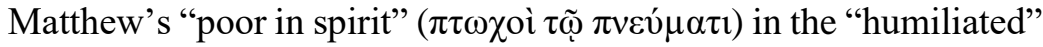
of Luke's Gospel ( $\tau \alpha \pi \varepsilon v v o i)$ or, in general, in the category "humiliation" ( $\tau \alpha \pi \varepsilon i v \omega \sigma ı)$ referred to in the Magnificat (Lk 1:48.52). ${ }^{45}$ He seeks the roots of the idea of "poverty in spirit" in the Hebrew category 'anāwîm and finds them in the attitude of

\footnotetext{
${ }^{42}$ See: B.T. Viviano, "Ewangelia według św. Mateusza," 926.

${ }^{43}$ GPNT, 15.

${ }^{44}$ A. Klawek, "Godzina Biblijna," 106. Let us add that this is the only blessing in the context of which Klawek mentions Mary in his commentary, placing her, next to Christ, as a model of living poverty understood in this way.

45 See: A.M. Serra, "Poverty of Spirit," 10.
} 
the heroes of the late Old Testament books (Judith, Est, 1-2 Macc, Dn). 'Anāwîm are people not only materially poor and oppressed by tormentors. It is above all those who humble themselves before God, remain obedient and faithful to His covenant and resort to Him in humble prayer. ${ }^{46}$ By translating these observations into the realities of the New Testament, Serra draws an interesting conclusion - based on both patristic tradition and biblical research - that the fundamental manifestation of Mary's spiritual poverty was her fiat. This observation, combined with an analysis of the Magnificat hymn, leads him to the conclusion that the "poverty in spirit" of God's servants is a "fertile space" in which God does "great things" (Lk 1:49). ${ }^{47}$

This analysis could, and even should, be taken even further. To this end, it is worth looking at the aspect of "humiliation" in the context of two Mary's encounters separated by her mountain pilgrimage, ${ }^{48}$ i.e., the meeting with the angel Gabriel (Annunciation) and the meeting with Elizabeth (Visitation). Mary, so generously endowed in the scene of the Annunciation, feels spiritually too poor, i.e., unworthy of such a great gift, perhaps even embarrassed

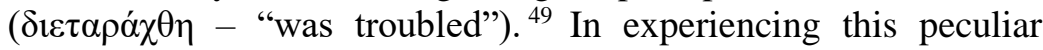
spiritual poverty, Mary feels the desire to make a pilgrimage and sets out to meet her neighbour, Elizabeth. Here the roles are reversed. Now Elizabeth experiences her spiritual poverty in the encounter with Mary's spiritual wealth and experiences a similar "confusion":

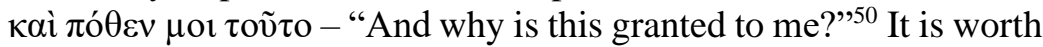
adding that Zachariah also reacts in the same way during his "Annunciation" - غ่ $\tau \alpha \rho \alpha ́ \chi \theta \eta$, i.e., he "was troubled," "was moved."

\footnotetext{
46 See: A.M. Serra, "Poverty of Spirit," 11-19.

${ }^{47}$ Cf. A.M. Serra, "Poverty of Spirit," 19-24.

${ }^{48}$ It is worth realizing how demanding this pilgrimage was: a 140-kilometre-long mountain crossing completed in a few days. Cf. B. Adamczewski, "Szczęśliwa, która uwierzyła," 78-79.

49 GPNT, 240.

${ }^{50}$ GPNT, 241.

${ }^{51}$ GPNT, 237. There are more Biblical examples where the hero experiences this kind of spiritual poverty, i.e., the "sense of unworthiness." This concerns also David, see: B. Adamczewski, "Szczęśliwa, która uwierzyła," 83; cf. S. Hahn, "Biblical Theology," 19.
} 
Here we reach the heart of the Mariological aspect of poverty and, at the same time, we realize how important the Mariological aspect is for a full interpretation of the eight beatitudes. Mary experiences her spiritual poverty mainly at the level of her personal encounter with God. Elizabeth experiences it in a personal encounter with Mary. In the reality of the meeting - but not just any meeting, because it is a meeting on the path of pilgrimage - we can observe a peculiar Mariological paradox of spiritual poverty and richness at the same time.

On the one hand, the meeting is initially associated with the experience of one's own spiritual deficiency, humiliation, confusion, embarrassment, a sense of inadequacy to the greatness of the gift received and, at the same time, the inability to give something to the other. ${ }^{52}$ But on the other hand, it is this meeting that later becomes a source of great wealth. The initial "humbling oneself," full of spiritual poverty, creates a "fertile space" in which God, by His grace and by meeting with the other, accomplishes "great things" which ultimately become a source of spiritual richness (cf. 2 Cor 8:1-9).

It is worth adding that Balthasar develops in a similar context the Mariological theory of "owing oneself to the other one" in the order and in the area of grace. ${ }^{53}$ And Tischner says that the wealth or treasure of the pilgrim is both the angel of the Annunciation and the other person encountered on the way of the pilgrimage. ${ }^{54}$

\section{2. "Blessed are those who mourn" (Matt 5:4)}

The reflection on this beatitude must begin with the question whether it really concerns just sorrow. In the original text, the word

\footnotetext{
52 Tischner shares an interesting observation on this subject: "This is what the miracle of meeting is about, that a person only now discovers how poor he or she is in relation to whom he or she met. He has met the other person and has nothing to give. What can a human being give to an angel for having come and brought a gift? What can a person give back? Only the greatness of the meeting showed her how low she was. It was the Annunciation that made her so impoverished." J. Tischner, Ksiązeczka pielgrzyma, 14.

53 See: J. Ratzinger, H.U. von Balthasar, Maryja w tajemnicy Kościoła, 114-122.

${ }^{54}$ Cf. J. Tischner, Książeczka pielgrzyma, 15.
} 
$\pi \varepsilon v \theta 0 \tilde{v} \tau \varepsilon \varsigma$, that is "sorrowful," is used. Popowski suggests even a much stronger, literal translation: "those being in mourning." 55 In such a case, it would be justified to speak not only of sadness, but also of crying. Mourning can be associated with authentic crying, but especially in Eastern cultures, this can also be the wailing of socalled "weeping mourners." There may, therefore, be different motives for making somebody adopt an attitude of sadness or weeping.

One can recall two different categories of crying people that can be found on the pages of Scripture. The first category refers directly to the attitude of those mentioned above who were oppressed under the pressure of various tormentors - the Old Testament 'anâwîm. It is worth returning for a moment to the Serra's analysis. He points out that the attitude of 'anāwim is clearly visible in the people of Israel in situations of captivity, exile and oppression. Babylonian captivity and, in particular, the oppression associated with the subsequent Greek and Roman occupation, lead the Israelites to return to the fidelity to the covenant, to place all their trust in God and to bring to Him prayers for liberation full of tears but also of trust. ${ }^{56}$ This situation is symbolically illustrated by the attitude of Susanna: "And she, weeping, looked up toward heaven, for her heart trusted in the Lord" (Dan 13:35). It is also partly reflected in the words of Psalm 137: "By the waters of Babylon, there we sat down and wept, when we remembered Zion" (Ps 137:1; cf. 1 Macc 7:36).

The second category is the group of women weeping under the cross. One can recall Christ's admonition addressed to them: "Daughters of Jerusalem, do not weep over me; weep over yourselves and over your children!" (Lk 23:28). Christ does not command these women not to cry at all. He does, however, draw their attention to what to weep over, i.e., not the effect, but the cause. ${ }^{57}$

It is not known whether the Virgin Mary present there was weeping under the cross (Jn 19:25). If so, then surely this "Daughter

55 GPNT, 15.

${ }^{56}$ See: A.M. Serra, "Poverty of Spirit," 11-17.

${ }^{57}$ Cf. J. Tischner, Ksiązeczka pielgrzyma, 21. 
of Zion," 58 was closer to the first of the categories described above, i.e., to Susanna and to those crying remembering Zion and asking God for the salvation of anâwim, than to the above mentioned "Daughters of Jerusalem." However, like poverty, sadness or weeping should not be reduced to a purely physical dimension. There can be no doubt that Mary lamented what was happening on Golgotha. Unfortunately, the Evangelists do not characterize this pain with any particular term. In any case, it is important that Mary, in contrast to the weeping women, did not need to be admonished by Christ, even though He also addressed Her personally (Jn 19:26).

This does not mean that the Gospels are completely silent about the pain of Mary. This question arises - again - in the context of the pilgrimage. It is necessary to refer to the biblical scene of the drama that Mary and Joseph experienced while searching for Jesus lost on his return from the pilgrimage to Jerusalem (Lk 2:41-51). Although the Greek term is not the same as in Matthew 5:4, Mary declares that

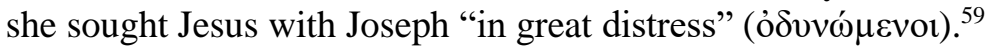

An interesting interpretation of this event is put forward by Tischner:

We remember the scene from the Jerusalem temple. Son, why have you treated us so? Behold, your father and I have been searching for you in great distress. And he said to them: Why were you looking for me? Did you not know that I must be in my Father's house? And they did not understand the saying that he spoke to them. Even they did not understand, let alone us! Yet there was a great truth in what Jesus told them - a truth that is achieved only by crying it over. ${ }^{60}$

The Mariological aspect of distress, which the second blessing refers to, carries the message that there are truths that we, like Mary and Joseph, not only do not understand, but which we will never understand in a purely speculative way. These are truths that are only

\footnotetext{
${ }^{58}$ Cf. A.M. Serra, "Poverty of Spirit," 9. More about this Marian title will be said in the analysis of the seventh beatitude.

${ }^{59}$ GPNT, 253.

${ }^{60} \mathrm{~J}$. Tischner, Książeczka pielgrzyma, 23.
} 
reached by "crying it over," that is, truths that reach the depths of human pain and human suffering. ${ }^{61}$

\section{3. "Blessed are the meek" (Matt 5:5)}

The analysis of the third beatitude must also begin with a brief reflection on the appropriateness of the above translation. In the original version there is an expression: $\mu \alpha \kappa \alpha$ ptor oi $\pi \rho \alpha \varepsilon i \tilde{\varsigma}$, and therefore in the exact translation it is something like "gentle." 62 Gregory of Nyssa, for example, explicitly discusses the notion of "gentleness" when he analyses this blessing. ${ }^{63}$

Being gentle and considerate are qualities that are usually associated with the female disposition. However, we should not yet try to find a Mariological context at this level. It should be remembered that a little further in the same Gospel, Jesus applies

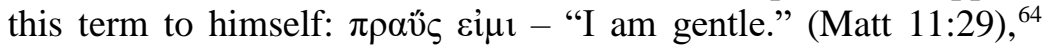
recommending that everyone follow him in this. Once again, it is clear that this is not about some physical innate trait, but about a conscious spiritual attitude. This kind of gentleness is another feature of 'anāwim, who in silent and humble prayer raise their eyes to the Lord.

The Marian aspect of such an attitude of gentleness, courtesy and humble acceptance of the Word of God resounds clearly in the scene of the Annunciation ( $\operatorname{Lk} 1: 29$ ). We have already interpreted the verb $\delta 1 \alpha \tau \alpha \rho \alpha ́ \sigma \sigma \omega$ before, characterising the confusion that accompanied Mary at the time. The second verb used by St. Luke in this verse, in turn, describes the state of reflection that the words of the angel

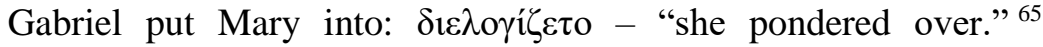

\footnotetext{
${ }^{61}$ To explore this problem, it is worth consulting the Apostolic letter of John Paul II Salvifici doloris.

${ }^{62}$ GPNT, 15. See also B.T. Viviano, "Ewangelia według św. Mateusza," 926. A gentle and delicate man is usually not noisy or loud, therefore the aspect of silence and quietness is undoubtedly within the semantic field of the adjective $\pi \rho \tilde{\alpha} o \varsigma$ (cf. J. Strong, Grecko-polski stownik, 643) and in the scope of this blessing - it is worth remembering, however, that it does not exhaust it.

${ }^{63}$ Gregory of Nyssa, Homilies on Beatitudes. Homily III, 40-46.

${ }^{64}$ GPNT, 50.

65 GPNT, 240.
} 
The reflection, full of gentle pondering and silence as well as the acceptance (in this case in both a literal and figurative sense) of the Word of God characterizes this very conscious spiritual attitude of Mary. ${ }^{66}$

An interesting interpretation of this attitude of gentleness and obedience to Mary, as a reversal of the attitude of rebellion displayed by Eve (Genesis 3:6), is proposed by Hahn. Referring to medieval poets, he shows, on the basis of a word-play, how Mary symbolically and literally reverses what Eve passed on to her offspring, and how the words of Annunciation are related to the words that Mary spoke in Cana (Jn 2:5):

The medieval poets summed up the matter neatly by pointing out that the Angel Gabriel's Ave (the Latin greeting) reversed the name of Eva. So also did it reverse the rebellious inclination Eve left to her children - to you and to me-and replace it with the readiness to obey, which Mary wants to teach us when she says: "Do whatever He tells you."

It is also worth noting that in the Mariological context, i.e., in the "episode" with the anonymous woman from the crowd (Lk 11:27-28) mentioned earlier, Christ seems to confirm once again the blessing discussed here. It concerns - as can be seen - all those who, following Mary's example, fulfilling her command from

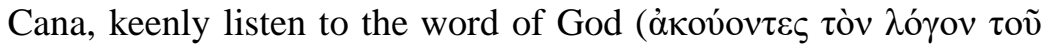
$\theta \varepsilon 0 \tilde{)}){ }^{68}$

Mary, who herself does not speak much on the Gospel pages, speaks much more clearly than by any words, not only through her obedience to God's Word, but also through her multiple actions: through her love (Lk 2:7), through her compassion (Jn 2:3) and

\footnotetext{
${ }^{66}$ C.S. Keener adds in his interpretation that "Mary expresses her submission to God's will in the traditional Old Testament language of submission or tacit consent." C.S. Keener, Komentarz historyczno-kulturowy, 125.

${ }^{67}$ S. Hahn, "Biblical Theology," 18.

${ }^{68}$ Cf. B. Adamczewski, "Szczęśliwa, która uwierzyła," 84-87.
} 
through the co-suffering she endures bravely throughout her life's pilgrimage, and in a particular way under the Cross (Jn 19:25). ${ }^{69}$

Here we deal with yet another Mariological paradox a meaningful silence. This paradox, incidentally, is a derivative of an analogous Christological paradox (the silent Word), that Balthasar writes about. ${ }^{70}$ Tischner rightly observes that only in the silence of profound Marian reticence and concentration it was possible to hear the voice of the promise, which was the voice of the Annunciation. ${ }^{71}$

However, the question can be asked at this point: is humble silence not a sign of fear or humiliation? The answer is: not if only the true motives for such an attitude are known. Clearly, precisely in the context of Mary's blessing, this is what Balthasar says:

Mary's humility is not the attitude of a repentant sinner. It is a joyful, free, childish humility of a person who would never think that whatever is in Her is Her property and not God's gift. "I will be blessed by all generations": these words themselves indicate the special nature of her humility. ${ }^{72}$

\section{4. "Blessed are those who hunger and thirst for righteousness" (Matt 5:6)}

At the beginning of the analysis of this blessing, as with the first one, we must explain that we do not discuss the issue of the exegetical hypotheses that Matthew added the term concerning

\footnotetext{
69 Tischner put it in beautiful words: "How many words did the Mother of Christ say on the pages of the Gospel? Not many. And the words she said were not a noise. Rather, they were a concentration of silence, a conversation, poetry, a humble request. The further the history of the Gospel went, the fewer words of Mother there were. At the end she fell silent. We would not know that she was under the cross if it was not for the Son. Where did it come from that she was so silent? We can guess - first it was because love was greater than a word, and then suffering was greater than a word." J. Tischner, Książeczka pielgrzyma, 18.

70 See: H.U. von Balthasar, Medytacja chrześcijańska, 32-39. Cf. H.U. von Balthasar, Duch chrześcijański, 88-98.

${ }^{71}$ Cf. J. Tischner, Ksiązeczka pielgrzyma, 18.

72 J. Ratzinger, H.U. von Balthasar, Maryja w tajemnicy Kościoła, 109.
} 
"justice." "3 We will only try to comment on the Mariological side of the biblical text we have before our eyes: $\mu \alpha \kappa \alpha ́ p$


hunger and thirst for righteousness. ${ }^{" 74}$

The beatitude presented in this form refers directly to the Old Testament tradition of the oft-repeated - especially in the Psalmstheme of the desire for God: "As a deer pants for flowing streams, so pants my soul for you, O God!" (Psalm 42:2), as well as the specific for prophetic tradition expectation of the Messiah (Saviour): "Shower, O heavens, from above, and let the clouds rain down righteousness; let the earth open, that salvation and righteousness may bear fruit; let the earth cause them both to sprout" (Is 45:8). The "earth" is to produce "fruit" - the Messiah, the "shoot from Jesse's trunk." (Is 11:1). This fruit will be brought to the world by the Virgin (Mary) (cf. Is 7:14). ${ }^{75}$ In the Mariological context, those biblical traditions are focused on what is popularly called the Marian "Rorate" service of Advent in Poland. ${ }^{76}$

However, biblical justice in question is very different from the contemporary, very narrow perception of the term. Once again, we need to refer to the category of 'anāwîm. It is the 'anāwim who represent a group of righteous people in the Hebrew sense of the word, which in contemporary European mentality would probably need to be expressed using the term "saints." Serra clearly indicates this in his analyses and as an example of the perfectly righteous 'anāwîm he gives us the main protagonists of the first chapter of St. Luke's Gospel, who today are not associated with narrowly understood justice, but with holiness in the broad sense:

Like Zachary and Elizabeth, Mary and Joseph were "just before God, walking in all the commandments and

\footnotetext{
73 See: B.T. Viviano, "Ewangelia według św. Mateusza," 926.

${ }^{74}$ GPNT, 16.

75 There is, of course, no room for the reproduction of an Exegetical-Mariological discussion on the messianic-Mariological interpretation of Is 7:14. An interested reader can consult: C. Stuhlmueller, "The Mother" and W. Most, "New Light."

76 The name of the service is taken from the first word of the Latin version of Isaiah in the translation of the Vulgate: "Rorate, cæli, desuper, et nubes pluant justum" (Is 45:8).
} 
ordinances of the Lord blameless" (cf. Lk 1,6). In a word, they had inherited the best of the 'anâwim tradition. ${ }^{77}$

In this context it should not come as a surprise that the beatitude we discuss here resounds almost verbatim in the Magnificat hymn. One could say that Mary sings the same truth that Christ proclaims in the Sermon on the Mount, only in a slightly different version:

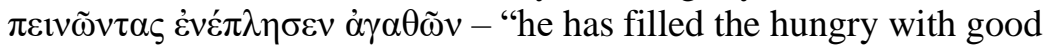
things" (Lk 1:53) ${ }^{78}$ The key link between the two statements is the verb $\pi \varepsilon \imath v \alpha \dot{\omega}$ - "to suffer hunger, privation," "to be in need, to strive for something." 79 It is worth noting that Mary speaks about satisfying the hungry with goods (in general), and not just food, for example. Once again we need to break away from the physical and material interpretation and move to the spiritual level - justice can then be qualified as one of these goods.

Mary is, however, not only the just one who brings the longawaited "Righteous one" to earth (deserving the title of Mother of Righteousness). Nor is her role limited to singing the beatitude discussed here in her Magnificat. She herself also becomes the subject of this blessing, sharing the plight of its addressees, and this in a double sense.

First, in a figurative sense. If, in the final analysis, the Messiah (Christ) is the "justice" referred to in this beatitude, then "hungry and thirsty for righteousness" are those who sincerely and determinedly seek God (Christ) in their lives. Mary, too, was forced to seek Him with great determination when He remained, unnoticed by her, in the temple ( $\mathrm{Lk} 2: 41-50)$. Another time she searched for Him and was forced to inquire about Him when He was teaching the crowds (Lk 8:19-20; Mk 3:31-35).

Mary also belongs to those who hunger and thirst for justice in the literal sense of the word, i.e., when she experiences-like other ordinary 'anāwîm-injustice, i.e., she is deprived of the goods that are rightly hers. These goods include, for example, the right to have

\footnotetext{
77 A.M. Serra, "Poverty of Spirit," 22.

78 GPNT, 243.

79 J. Strong, Grecko-polski słownik, 601.
} 
a home, a homeland and, above all, the right to respect for the dignity of another human being.

The Mariological biblical theme is very extensive here, although this time it concerns not only Mary herself, but the entire Holy Family, which must endure the wandering ( $\mathrm{Lk} 2: 4-5)$, which included being refused the place in an inn ( $\mathrm{Lk} 2: 7)$. Then comes the exile from the homeland (Matt 2:13-14) caused by the unjust sentence passed on the Child Jesus (Matt 2:16). The whole situation concludes with the highest act of injustice in the history of mankind, that is, a sentence-this time executed-on her innocent Son (Matt 27:23-26).

The most important thing is, however, the fact that the desire for justice has nothing to do with the desire for revenge or retaliation. ${ }^{80}$ Mary and Joseph, despite the many wrongs they have suffered, undertake their work and pilgrimage from day to day, do not think about revenge, forgive and thus do not stop on their way. ${ }^{81}$ Thus the theme of forgiveness appears on the horizon, which naturally brings us into the area of issues related to the next beatitude.

\section{5. "Blessed are the merciful" (Matt 5:7)}

The Mariological aspect of mercy seems obvious. The Mother of Mercy, the title of Mary from Vilnius "Gate of Dawn," is-besides the Black Madonna, her title of Jasna Gora-probably the best known Mary's appellation, most frequently used in native devotion. In popular Marian piety, there have often been many exaggerations and mistakes in granting various titles to the Mother of God. In some "traditions," alienated from the Bible, Mary has been portrayed as the Queen of the Kingdom of Mercy, while God the Father - and sometimes even her Son (given the title of "Just," misunderstood in

\footnotetext{
${ }^{80}$ Cf. B.T. Viviano, "Ewangelia według św. Mateusza," 926.

${ }^{81}$ Tischner adds in his reflection: "How much harm was done to a simple working man? And the man forgave, forgot and went to do his daily duty. We carry it all to the feet of the Queen of Poland. May she make those who hunger and thirst for justice satisfied - according to the words of her only Son," J. Tischner, Ksiazieczka pielgrzyma, 28-29.
} 
this case, although fully appropriate, as we have seen above) were supposed to exercise a strong-arm rule in the Kingdom of Justice. ${ }^{82}$

Any reflection on mercy must therefore begin by stating the basic fact that God is its source. And Mary, as "blessed," "full of grace" and "happy" - is the one who in the fullest measure experiences mercy (in her immaculate conception), God's grace (in the virgin conception of her Son and in her ascension) and true happiness (in her Divine motherhood).

Hahn proposed an interesting Biblical typological interpretation of the Marian dogmas mentioned here. In three basic Old Testament categories - creation (Eve), exodus (Ark) and kingdom of David (Queen-Mother) - he sees an announcement (type) of the most important events in Mary's life (anti-type) and, consequently, of Marian dogmas. ${ }^{83}$

So Eve, in particular, as the first living woman, from the first moment of her personal existence in the state of supernatural gift of sanctifying grace (Gen 2:15-25) is in this approach a type of Mary, immaculately conceived and full of grace (Lk 1:28). ${ }^{84}$ The untouchable Ark (Num 1:51; 1 Chron 13:10), which bears the word of God engraved in stone (2 Chron 5:10) and enters the gates of the holy city of Jerusalem (1 Chron 15:1-16:43), is a type of the unblemished Virgin ( $\operatorname{Lk} 1: 27)$, who bears the incarnated word of God (Lk 1,31-35) and enters the temple gates of the heavenly Jerusalem (Rev 11:19-12,1). ${ }^{85}$ Finally, Mary, as God's Mother (Lk 2:6-7), i.e., the Mother of the Messiah-King (Is 7:14) of the House of David (Lk 1:32), becomes the Queen-Mother, the anti-type of the Old Testament Gebirah, and consequently the Queen of

\footnotetext{
${ }^{82}$ The echoes of these "traditions," which go back to the works of Alfonso Liguori, are still present in some of the Marian songs. (eg. Serdeczna Matko), as well as in the demands of some movements seeking to establish so-called maximalist titles or even Marian dogmas. We would like to refer the reader interested in this issue to: K. Kowalik, "Piąty dogmat?," 81-99.

${ }^{83}$ Cf. S. Hahn, "Biblical Theology," 14.

${ }^{84}$ Cf. ibid., 17.

${ }^{85} \mathrm{Cf}$. ibid., 18-21. In this context Hahn makes an interesting juxtaposition of Elizabeth's cry when she was visited by Mary (Luke 1:42) with the cries and songs that accompanied the transfer of the Ark of the Covenant (1 Chronicles 15:28; 16:4-5; 2 Chron 5:13).
} 
Heaven (Regina caeli), the new eternal Kingdom of her Son. ${ }^{86}$ A further interpretation of these dogmas in the Christological dimension is made by Balthasar, pointing to the extremely deep relationship between the dogmas of immaculate and virginal conception and, respectively, the human and Divine aspects of the Chalcedonian dogma. ${ }^{87}$

Of course, one need not agree with all the details of the interpretations proposed by the theologians quoted here. One thing remains certain, however: all these events, focused like in a lens in Mary's life and formalised by the Church's Tradition and Magisterium in the form of Marian dogmas, are a momentous testimony to "great things" $(\mu \varepsilon \gamma \alpha \dot{\alpha} \lambda \alpha),{ }^{88}$ that is the great works of God's mercy that God has performed in the life and the person of Mary, about which she gratefully sings in the Magnificat hymn (Lk 2:46-55).

It is worth emphasizing that from among many Greek terms that can be used to express the realities of mercy and grace, in this hymn the noun $\ddot{\varepsilon} \lambda \varepsilon \varepsilon_{\varsigma}$ is chosen twice (Lk 1:50.54). It has a common root with the terms appearing in the beatitude: $\dot{\varepsilon} \lambda \varepsilon \eta \dot{\eta} \mu \mathrm{ov \varepsilon \varsigma}-$

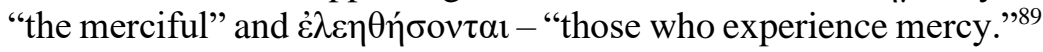

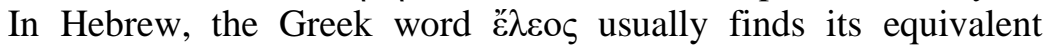
in hese $\underline{d},{ }^{90}$ which in its rich semantic field contains not only meanings related to grace and mercy but also to patience, fidelity, solidarity, rightness, staying in covenant and sometimes even justice. $^{91}$

If we combine the reflections on the Mariology of the present and the previous beatitude, we can see that Mary simultaneously praises God's justice and God's mercy, so, in a way, she personally

\footnotetext{
${ }^{86}$ Cf. S. Hahn, "Biblical Theology," 22-26.

${ }^{87}$ See: J. Ratzinger, H.U. von Balthasar, Maryja $w$ tajemnicy Kościoła, 53-69, 91-94.

88 GPNT, 242.

${ }^{89}$ GPNT, 16.

${ }^{90}$ Cf. J. Swetnam, "Hesed w Starym Testamencie," 251-260.

${ }^{91}$ An example of where Septuaginta translates hesed not only through $\varepsilon \lambda_{\varepsilon} \varepsilon \varsigma$ itself, but also through $\delta 1 \kappa \alpha 10 \sigma u ́ v \eta v$, is Ex 34.7. More on the exegetic analysis of this verse and the Hebrew semantic field hesed in: J. Lemański, "JHWH - Bóg," 19-43; J. Seremak, "Paradygmat zbawczej obecności," 150-156.
} 
distances herself from the aforementioned tendencies which are trying to present these realities as opposites. In her hymn, as in the Hebrew hesed, both of these realities are in harmony. This translates into another Mariological paradox, albeit more apparent than real: Mary deserves the title of Mother of Justice to the same extent as the Mother of Mercy.

While discussing the previous beatitude we juxtaposed the longing and striving for justice with the desire for revenge and retaliation. It is worth going further in this direction and now juxtaposing mercy with its opposite. It will certainly not be justice, for it is precisely the opposite of mercy (and not mercy itself!) that lies at the root of all injustice. Unnecessary contrasting the justice with mercy stems, perhaps, from an incorrect identification of the real opposite of mercy. For it is cruelty that is the true opposite of mercy.

It is Mary herself, forced to endure the unimaginable hardships of the flight to Egypt, as well as of the stay there and the return to her homeland (Matt 2:13-15.19-23), who clearly instructs us about this in the pages of the Bible. She experienced the consequences of Herod's cruelty, which led him to pass such an extremely unfair sentence on innocent infants (Matt 2:16). ${ }^{92}$

\section{6. "Blessed are the pure in heart" (Matt 5:8)}

The fundamental issue that connects the sixth beatitude with Mariology is obviously the motif of heart ( $\alpha \rho \rho \delta i \alpha)$. Mariological reflection on this problems seems to develop in two directions. A typical example of these two directions can be seen in the approach of Ronald Bagley.

On the one hand, the theme of Mary's heart is part of the deep biblical current of reflection on Mary in the already discussed broad context of 'anāwîm, i.e., the handmaid of the Lord, poor in spirit, gentle and quiet, who "treasured up all these things, pondering them in her heart" (Lk 2:19; cf. Lk 2:51). In this context, Bagley

92 Tischner draws exactly the same conclusions-although from a completely different reasoning - and gives his reflection on this beatitude a meaningful title: Mercy and cruelty. (J. Tischner, Ksiązeczka pielgrzyma, 31-34). 
undertakes a profound reflection on the birth of Christ by Mary not only through her womb, but above all through her heart: "The divine maternity would not have profited Mary if she had not first borne Jesus Christ in her Heart more happily and advantageously than in her womb." 93 This thought fits into the categories of "reflexive circularity" paradox discussed earlier and the interpretative advantage - in the context of the beatitudes - of the spiritual aspects of Mary's life over material aspects (cf. the problems of poverty, weeping, gentleness).

On the other hand, however, there is the maximalist Mariological current, developing for centuries along a completely different path, which often becomes attached to the context of the otherwise absolutely rightful devotion to the Immaculate Heart of the Virgin Mary. This current aims at developing Marian titles and giving the heart of Mary the rank that equals it not only in the sense of reverence, but sometimes even in the literal sense with the Heart of the Saviour. It is about an exaggeration analogous to those already mentioned in the context of the beatitude of mercy. For example, Bagley, referring to the work of the $17^{\text {th }}$ century French mariologist Jean Eudes, seems to be claiming, or at least to reproduce his claims, that: "Jesus lives and reigns so really in the Heart of Mary that it is possible to say that He is the Heart of Mary" 94 or: "The Heart of Jesus and the Heart of Mary are One and the Same Heart." 95 The attempts made there to derive such claims from Christological biblical texts (Jn 15:4; Jn 17:21-23) do not seem to be appropriate and one may wonder whether they are useful for Mariology. ${ }^{96}$

Much more fruitful - in the context of the beatitude we are currently analyzing - will be the deepening of the reflection towards the biblical-Mariological title of "handmaid of the Lord" (Lk 1:38).

\footnotetext{
${ }^{93}$ Cf. R.M. Bagley, "The Heart of Mary,” 131.

94 Ibid., 132.

95 Ibid., 133.

${ }^{96}$ More on this type of exaggeration, in particular: K. Kowalik, "Per Mariam ad Iesum," 25-30. In this study, the author notes that in the maximalist approach there are sometimes almost races for titles in which Mary is not only supposed to match Christ, but even surpass him: "Marian devotion in the aspect described here arrives actually at a level of equality between Christ and Mary with an indication to Mary." Ibid., 28.
} 
Purity of heart, as promised in this blessing, allows one to see God. So the question must be asked: what Marian attitude opens us up to this ability? The answer lies precisely in the attitude of the handmaid. The original text uses the term $\delta$ ov́ $\lambda \eta$, which, as Popowski suggests, can even be translated as a "slave." 97 It is worth noting that it is precisely the title of "handmaid" that Mary associates in the Magnificat most closely with eight beatitudes, using the word

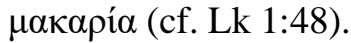

Balthasar proposes a very interesting reflection on this Marian title. He notes another Mariological paradox here. Mary through being a handmaid (or even better: a slave!), becomes a queen (of heaven, angels, peace, the Church, etc.). ${ }^{98}$ As Queen of Heaven, Mary certainly sees God. However, she deserves the title of queen only as much as she was ready to accept the title of handmaid/slave.

The attitude of serving is, therefore, a recipe for being able to see God as Mary did and interpret His will and expectations for the reality of one's life. Yet, Tischner will add another important condition here. This is, contrary to appearances, precisely a condition of purity of heart. It consists in removing the motive of curiosity that pollutes our intentions and obscures our spiritual gaze:

Do you want to know what God expects of us today? Consider and see what our duty is today. But you will not see or understand anything if it is only to satisfy your curiosity. Only then will you see when you say: "[...] I am asking in order to serve." 99

This reflection brings to mind a certain remark, perhaps exceptionally topical in our times. Such mundane terms as "service" and "duty" seem to be extremely distant from the heights of "spiritual rapture," with which all kinds of mystical experiences of seeing God are usually associated. Without wishing in any way to deny or undermine the value of authentic mystical experience, it should be noted that the Marian aspect of seeing God displayed here, which consists in faithfully fulfilling one's, perhaps even the

97 GPNT, 240.

${ }^{98}$ See: J. Ratzinger, H.U. von Balthasar, Maryja w tajemnicy Kościoła, 87-89.

99 J. Tischner, Książeczka pielgrzyma, 38. 
most mundane, duty (such as everyday life in Nazareth), should be a signpost for all those who believe that God can only be found or seen in emotional rapture or various kinds of extra-natural phenomena.

\section{7. "Blessed are the peacemakers" (Matt 5:9)}

Following the reflections on the previous beatitudes, we could also start here by mentioning Mary's title of Queen of Peace, which is relevant to this subject. We will also refer to this, but earlier we will be interested in another Mariological title, deeply set in the biblical texts, because in its roots it goes back to the Old Testament.

Introducing peace, according to the promise included in this beatitude, makes Christians vioì $\theta \varepsilon$ ov - "sons of God." ${ }^{100}$ Mary heralds this reality and she herself already participates in it in a special way as $\theta 0$ r $\alpha \tau \varepsilon \rho \Sigma \omega \omega v$ - "the daughter of Zion." It is worth quoting here an adequate verse from the prophet Zephaniah in its entirety, so as to be able to see how deeply it matches both the angelic greeting and the Magnificat: "Sing aloud, O daughter of Zion; shout, O Israel! Rejoice and exult with all your heart, O daughter of Jerusalem!" (Zeph 3:14). ${ }^{101}$

Those who introduce peace become the "sons of God" and "daughters of Zion," that is those who attain the joy of living in God. Ratzinger undertook a deep reflection on this issue, returning in this context precisely to the scene of Annunciation:

"Rejoice" - why can Mary rejoice in such a world? The answer is "The Lord is with you." To understand the meaning of this announcement, we need to look again at the basic texts of the Old Testament, which pertain to it, especially Zephaniah. They always contain a double promise to Israel, the daughter of Zion: God will come as the Saviour and dwell in it. The angel's conversation with Mary is

\footnotetext{
${ }^{100}$ GPNT, 16.

${ }^{101}$ An ample description of the history of research on the correlation of the texts discussed here can be found in: N. Lemmo, "Maria, 'Figlia di Sion." "It is also worth


et théologique."
} 
a reference to this promise and causes it twofold concretization. What the prophetic words say about the daughter of Zion now relates to Mary: she is identified with the daughter of Zion, who she is herself. And parallel to this, Jesus, whom Mary is to give birth to, is identified with Yahweh, the living God. ${ }^{102}$

In other words, on the base of these considerations, we can paraphrase the present beatitude as follows: blessed are the peacemakers, for they become sons in the Son and daughters in the Daughter.

But let us come back to the issue of peace. The fact that Mary is

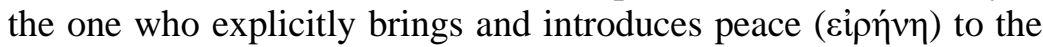
earth, which the seventh blessing speaks of, is best expressed through her Divine motherhood. In the context of the first visit paid to Mary and the newborn Jesus by shepherds (Lk 2:8-20), the announcement of "peace on earth" resounds in angelic voices: غ̇ंì

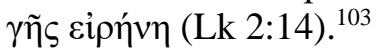

Directly after the visit of the shepherds, Luke goes to the scene of the Presentation (Luke 2,21-38), during which the famous prophecy of Simeon is uttered. Mary brought peace to earth, so the

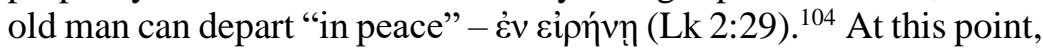
a kind of relay-like generational change is taking place. Simeon does indeed leave in peace, but in his prophecy he passes on to Mary the "baton of anxiety," which is his famous "sword" (Lk 2:35). So here we come to discover another Mariological paradox. Mary, Queen of Peace, is to be at the same time the one whose heart is pierced by the sword of anxiety. The peace that Mary brings to the world cannot be understood in worldly terms: "Do you think that I have come to give peace on earth? No, I tell you, but rather division" (Lk 12:51).

The problem of "Simeon's sword" leads us directly into the next beatitude.

102 J. Ratzinger, H.U. von Balthasar, Maryja w tajemnicy Kościoła, 56. More on this topic: J. Ratzinger, Córa Syjonu.

103 GPNT, 248.

104 GPNT, 250. 
8. "Blessed are those who are persecuted for righteousness" (Matt 5:10)

The last beatitude, considered in the Mariological context, connects, like a bridge, the joyful and charitological Marian title "full of grace"- and therefore, as previously stated, also "happy" ( $\mu \alpha \kappa \alpha \rho i ́ \alpha)$-with the so-called "Simeon's sword" theme (Lk 2:35), that is, with the "being persecuted" that is the subject of this blessing.

Both Ratzinger and Balthasar undertake reflection on this highly paradoxical issue. ${ }^{105}$ It is the German theologian who perceives this extraordinary synthesis that occurs between "rejoice" that Mary hears at the moment of Annunciation and the "sword of co-suffering" that pierces her under the cross:

However, because human life always involves suffering, that is why the image of the suffering Mother, the image of rahamim of God, has taken on such great significance for Christianity. It is only in Her that the image of the Cross comes to its end, because She is the accepted Cross, borne in co-suffering and this Cross allows us to experience God's co-suffering in Her co-suffering. Thus the Mother's pain is the paschal pain, which already opens up the transformation of death into the proper salvific being together with the other one. We have only seemingly moved away from the "rejoice" from which Mary's story begins. For the joy announced to her is not a trivial joy, forgetting the abyss of our being and thus doomed to fall into a vacuum. [...] Authentic joy can only be the one that faces suffering and is stronger than that suffering. ${ }^{106}$

While discussing the fifth beatitude, we noticed that Mary in her Magnificat praised God's hesed/eleos, i.e., the faithful Father's mercy. And Ratzinger notes that in her own life she realized this second, complementary, maternal face of mercy, usually expressed in biblical terms rahamîm/oiktirmos, characterized by

${ }^{105}$ See: J. Ratzinger, H.U. von Balthasar, Maryja $w$ tajemnicy Kościoła, 65-69, 94-96.

${ }^{106}$ Ibid., 68. 
compassionate care, full of co-suffering love, and, at the same time, this unique kind of joy that a woman experiences as soon as she overcomes the birth pangs (cf. Jn 16:20-22).

The Swiss theologian sees in this context the calling undertaken by Mary, but also addressed to every Christian, to grow constantly and purify one's faith in the fire of suffering and persecution:

The sense of this constant education of Mary towards the pure faith and towards standing at the foot of the Cross is often not sufficiently understood. We are amazed and embarrassed by the way Jesus deals with his Mother, whom he addresses both at Cana and at the Cross as "Woman." He himself is the first to brandish the sword that must penetrate her. But if He did not do so, how could she have matured? How could she remain under the Cross, where not only the earthly failure of her Son seems obvious, but also the Father, who has sent Him, abandoning Him? ${ }^{107}$

These reflections are complemented by Tischner, who, deepening the distinction made above between craving for justice and the desire for revenge, will reflect on the difference between disaster and the cross. Someone who concentrates in his life on dealing with the misfortunes and wrongs which have befallen him, stops at a standstill, becomes a slave to retaliation and, as a result, stops making his pilgrimage. Conversely, a pilgrim is able to see the difference between complaining about a misfortune and carrying a cross with a loving attitude. ${ }^{108}$ It is in this context that Tischner also refers to the problem of the "sword of Simeon," noting the inseparable connection between its two faces: Mariological and Christological.

107 Ibid., 96.

108 Tischner treats the difference as follows: "The cross is infinitely more than misfortune. The cross is a testimony. The testimony proclaims: there are stronger and higher values than those from which the misery strips us. 'Soul cannot be killed.' Yes, there is an absolute limit to violence. There is something that 'they cannot kill.' That is where your love must be placed, for ' $[\ldots]$ where your treasure is, there is your heart." J. Tischner, Ksiązeczka pielgrzyma, 41. 
How many times misfortune comes, we know: it could be different. There could be no earthquake, no river flooding, no hail. You cannot say that about a cross. This chalice must be drunk to the bottom. "And your own soul will be penetrated by a sword, so that the thoughts of the hearts of many will come to light," Simeon said to Mary. "If the grain does not die, it will not bear fruit," said Christ. ${ }^{109}$

The above quotation can be generalized, summing up all the reflections made here: the Christological face of the eight beatitudes is inextricably linked and reflected, as if in a perfect mirror, in their Mariological face.

\section{Proclaiming the Kingdom of God}

At the beginning we have indicated that the goal of this paper consists not only in theoretical analyses of the texts related to the eight beatitudes and of Mary's attitude to life. We want this work to have an impact also on the pastoral dimension.

The text of the beatitudes in Matthew 5:3-10 has been edited in such a way as to make the Kingdom of God its central theme although formally present in the compositional clasp only in the first and last blessing, its substance encompasses the whole of the pericope. The proclamation of the Kingdom of God and the call to conversion are, in fact, the superior motifs of the whole Sermon on the Mount. ${ }^{110}$

These issues are also the central (third) mystery of the new part of the rosary introduced by John Paul II, which includes the so-called luminous mysteries. ${ }^{111}$ While discussing these mysteries, the Pope shared the following reflection, concerning them as

\footnotetext{
109 Ibid., 41.

${ }^{110}$ Cf. B.T. Viviano, "Ewangelia według św. Mateusza," 925-938.

${ }^{111}$ When discussing the third mystery of light, the Pope wrote: "Another mystery of light is the preaching by which Jesus proclaims the coming of the Kingdom of God, calls to conversion," see: John Paul II, Apostolic letter Rosarium Virginis Mariae, 21. The quintessence of this teaching of Jesus certainly includes eight blessings.
} 
a whole: "In these mysteries, apart from the miracle at Cana, the presence of Mary remains in the background." 112

The Pope clearly states that Mary is present in all these mysteries. One can guess that he left it to theologians to undertake in their studies the effort to bring her figure out of this background. ${ }^{113}$

This task seems to be undertaken by Casarella in his work. He rightly suggests that Mary's words from the second luminous mystery: "Do whatever she tells you" (Jn 2:5), are a direct echo of the words of God the Father himself from the first and fourth mysteries: "This is my beloved Son, in whom I am well pleased" (Matt 3:17) and "This is my beloved Son, listen to him!" (Mk 9:7). ${ }^{114}$ In the context of the fifth mystery, Mary's words harmonize with those of Christ, who this time himself commands His disciples: "do this in memory of me!" (Lk 22:19).

The question remains for us: what about the third mystery? Casarella has a good intuition here, because he senses that it is necessary to head towards beatitudes. When considering the third mystery, he writes: "this mystery recalls the beatitude, 'Blessed are the peacemakers." "115 Without giving any justification, however, he restricts himself to this one beatitude.

Yet, to notice how much the Marian aspect resounds in Christ's words also in this mystery, it is necessary to look at the Beatitudes as a whole - precisely in the context of their Mariological interpretation presented in this work. Of course, as in the case of

\footnotetext{
112 John Paul II, Apostolic letter Rosarium Virginis Mariae, 21.

113 Over the last two decades, a large number of academic and popular science works on Mariological reflection on the mysteries of light have been created on both domestic and international grounds. Among those that fit within the framework of the biblical-Mariological deliberations adopted here, it is worth mentioning the studies of the authors we have already referred to before, i.e., Kudasiewicz and Langkammer (J. Kudasiewicz, Nowe tajemnice and H. Langkammer, Dlaczego), the historically and biblically oriented elaboration by Jerome Vereb (J. Vereb, Pope John Paul II) and the deeply biblically and patristically - although not Mariologically_embedded reflection by Tim Gray (T. Gray, The Luminous Mysteries). Finally, it is worth adding that Balthasar also left behind deep meditations on the mysteries of the Holy Rosary (H.U. von Balthasar, Rosary), but they could not possibly cover the mysteries of light.

114 Cf. P. Casarella, "Contemplating Christ," 167.

115 Ibid., 166.
} 
other mysteries, Mary remains and should remain here in the background. Nevertheless, it is worth showing how rich this background is and how much Mariological reflection can enrich Christological reflection on this mystery.

To this end, reference needs to be made to the study carried out by Gérard Rossé, who, when considering this mystery in the context of the Kingdom of God, drew attention to two important aspects of this fundamental biblical concept:

a) Kingdom of God as a place which is entered by those who are capable of being transformed and becoming like children (Matt 18:3).

b) The Kingdom of God as a harbinger of a new order which radically breaks with the order of the earthly world. ${ }^{116}$

In the context of the present paper, the first aspect refers to the extensively discussed here dimension of the 'anāwîm pilgrims who, as the "little ones," by making a pilgrimage through their lives on the path of eight beatitudes, enter this Kingdom through a narrow gate. This aspect, as we have already pointed out in the introduction, is nothing new, nor is there a lack of studies of the mysteries of the Rosary, referring to this "pilgrim" theme. ${ }^{117}$

Much more interesting from the point of view of the present reflection is the second aspect. The new order of the Kingdom of God is so different from the order of the kingdoms of this world that it makes the impression of being completely paradoxical. Mary's whole life-just like the life of anyone who seriously decides to follow the path of the eight beatitudes - has been deeply interspersed with many paradoxes. Contrary to appearances, it was not "elegantly arranged," as some "over-sentimental" interpretations suggest.

The analyses carried out in this paper have clearly shown that there was room for calm and gentleness in her life, but also for the rush and extreme hardships of pilgrimages, there was place for the harmonious singing of mercy and justice and for

${ }^{116}$ Cf. G. Rossé, "The mysteries of light," 18-20.

117 See for example: S. Szczepaniec, Rekolekcje oraz M.B. Pennington, 20 tajemnic różańca. 
experiencing cruelty and injustice, and finally, there was room for great joy, but every now and then pierced with the sword of suffering.

\section{Conclusion}

Certainly not all the Mariological aspects of the theme of the eight beatitudes have been exhausted in this paper, especially with regard to the application of the analyses carried out here to the more practical fields of theology. Such completeness was not the ambition of its author. The primary goal was to stimulate contemporary theological reflection in a sector of research that has a huge (although, according to the author, not yet sufficiently exploited) potential for development, and which can be described as biblical Mariology.

The areas of application proposed or merely signalled here in the field of the new evangelization, the new feminism, the meditation on the mysteries of the rosary, or at least in the field-highlighted here after Tischner, but by no means exhausted - of reflection on the theology of pilgrimage, so deeply inscribed, on the one hand, in Marian devotion and, on the other hand, in the reality of the eight beatitudes, can certainly become worthy topics for further in-depth and extended analyses.

The main theme of the Mariological and biblical reflection presented here was the thought of Benedict XVI, who considered evangelical beatitudes to be a new programme of Christian life. The third luminous mystery proposed by John Paul II calls for the realisation of this programme. The reflections contained in this work can be regarded as a concrete proposal to implement this programme in the light of the biblically documented life experience and personality of Mary.

Finally, therefore, it is worth drawing eight synthetic conclusions from the analyses presented, which show how the Kingdom of God can be proclaimed in the modern world, following Mary on one's own life path of the eight beatitudes:

1. Through Mary's poverty, which, although also lived on a material level, reaches its peak in humility and in the need to meet both the angel of the Annunciation and others (Elizabeth). Such 
poverty opens up to the acceptance of a gift and consequently becomes a source of true wealth.

2. Through Mary's pain, which, when confronted with the Jerusalem women's weeping, teaches us that it only makes sense to cry over the cause and not effect, and that there are truths that cannot be known by inquiry, but only by "crying over them."

3. Through Mary's gentleness, which shows that with everyday humble and joyful deeds (Nazareth), compassion (Cana) and co-suffering (Golgotha), much more can be said than through an endless, noisy stream of words.

4. Through the longing and thirst for justice, which fill Mary's life, and which has nothing to do with a desire for revenge and retaliation. Any person who would succumb to taking revenge for the wrongs he or she have suffered would stop on their way and stop making their pilgrimage.

5. Through the Marian experience of Divine Mercy and human cruelty, which-especially in the context of Herod's heinous sentence-makes us realize that the true opposite of mercy is not justice, but cruelty.

6. Through Mary's purity of heart, which consists above all in freedom from an attitude of curiosity and in the ability to see God obtained through the conscientious exercise of the duties of a handmaid, who precisely in this way becomes queen.

7. Through the external and internal peace that reigns in Mary's heart, which is not to be confused with ordinary peace and which is not the "peace" of this world, but the peace of those who in Christ become "sons in the Son" and in Mary "daughters in the Daughter."

8 Through the "Simeon's sword" penetrating the heart of Mary, hearing the word "rejoice" at the Annunciation, which indicates that only a joy that is not afraid to face suffering is authentic and stronger than this suffering.

\section{Acknowledgements}

The author of this work would like to express his thanks to Fr. Bartosz Adamczewski, PhD, Professor at the UKSW, for his valuable comments 
and guidance, which have contributed significantly to deepening and broadening the analyses contained therein.

\section{Bibliography}

Adamczewski, B., "Szczęśliwa, która uwierzyła (Łk 1,45)," Verbum vitae 5 (2004), 75-87.

Augustyn z Hippony, O kazaniu Pana na Górze. Do Symplicjana o różnych problemach. Problemy ewangeliczne, S. Ryznar, J. Sulowski (transl.), Warszawa 1991. = Augustine of Hippo, Commentary on the Lord's Sermon on the Mount, with Seventeen Related Sermons, D.J. Kavanagh (transl.), Washington, D.C. 2001.

Bagley, R.M., "The Heart of Mary, Model of Love: Marian Dimension of the Millennium Preparation," Marian Studies 50 (1999), 127-138.

Balthasar, H.U. von, Duch chrześcijański, Z. Włodkowa (transl.), Poznań 2013. = Balthasar, H.U. von, Elucidations, J.K. Riches (trans.), San Francisco (CA) 1998.

Balthasar, H.U. von, Medytacja chrześcijańska, W. Szymona (transl.), Poznań 2014. = Balthasar, H.U. von, Christian Meditation, San Francisco (CA) 1989.

Balthasar, H.U. von, Różaniec: zbawienie świata w modlitwie maryjnej, Jan Koźbiał (transl.), Wrocław 1998. = Balthasar, H.U. von, The Threefold Garland: The World's Salvation in Mary's Prayer, San Francisco (CA) 1982.

Barzun, J., The Culture We Deserve: A Critique of Disenlightenment, Middletown (CT) 1989.

Buby, B.A., Biblical Methodology and Mariology. The Use of Bibical Methodologies in Marian Theology Today, https://udayton.edu/imri/m ary/b/biblical-methodology-and-mariology.php (access: 16.05.2020).

Casarella, P., "Contemplating Christ through the eyes of Mary: The Apostolic Letter Rosarium Virginis Mariae and the New Mysteries of Light," Pro Ecclesia: A Journal of Catholic and Evangelical Theology 14 (2005) no. 2, 161-173.

Catechism of the Catholic Church, https://www.vatican.va/archive/ENG 0015/_INDEX.HTM (access: 29.08.2020).

Dodd, G.F., "Feminist and New Feminist Perspectives on Mary: Renewal or Retrieval?," Marian Studies 65 (2014), 277-327.

Fausti, S., Wspólnota czyta Ewangelię wedlug św. Mateusza, Częstochowa 2007. 
Feuillet, A., Jésus et sa mère : d'après les récits lucaniens de l'enfance et d'après saint Jean : le rôle de la Vierge Marie dans l'histoire du salut et la place de la femme dans l'Église, Paris 1978.

Gray, T., The Luminous Mysteries: Biblical Reflections on the Life of Christ, Steubenville 2005.

Grecko-polski Nowy Testament. Wydanie interlinearne $z$ kodami gramatycznymi [GPNT], R. Popowski, M. Wojciechowski (transl.), Warszawa 2003.

Gryglewicz, F., Błogostawiona przez wszystkie narody Matka Boża w Nowym Testamencie, Częstochowa 1984.

Grzegorz z Nyssy, Homilie do błogosławieństw, M. Przyszychowska (red.), Kraków 2005. = Gregory of Nyssa, Homilies on the Beatitudes, Drobner, H., Viciano, A. (eds.), Leiden 2000.

Hahn, S., "Biblical Theology and Marian Studies," Marian Studies 55 (2004), 9-32.

Häring, B. Pieśń stugi; Błogosławieństwa; Eucharystia, A. Mysłowska, A. Łobocka-Oleksowicz, M. Mroszczak (transl.), Warszawa 1982.

John Paul II, Apostolic letter Rosarium Virginis Mariae, http://www.vatican.va/content/john-paul-ii/en/apost_letters/2002/ documents/hf_jp-ii_apl_20021016_rosarium-virginis-mariae.html (access: 29.08.2020).

John Paul II, Apostolic letter Salvifici doloris, http://www.vatican.va /content/john-paul-ii/en/apost_letters/1984/documents/hf_jp-ii_apl_ 11021984_salvifici-doloris.html (access: 29.08.2020).

John Paul II, Encyclical Redemptoris Mater, http://www.vatican.va/ content/john-paul-ii/en/encyclicals/documents/hf_jp-ii_enc_2503198 7_redemptoris-mater.html (access: 29.08.2020).

Keener, C.S., Komentarz historyczno-kulturowy do Nowego Testamentu, K. Bardski, W. Chrostowski (ed. of the Polish edition), Warszawa 2010. = Keener, C.S., The IVP Bible Background Commentary: New Testament, Downers Grove (IL) 1993.

Klawek, A., "Godzina Biblijna - Osiem Błogosławieństw," Ruch Biblijny $i$ Liturgiczny 20 (1967) no. 2, 103-109.

Klemens Aleksandryjski, Kobierce zapisków filozoficznych dotyczacych prawdziwej wiedzy, vol. 1-2, J. Niemirska-Pliszczyńska (ed.), Warszawa 1994.

Kowalik, K., "Per Mariam ad Iesum. Per lesum ad Mariam," Salvatoris Mater 3 (2001) no. 2, 22-33.

Kowalik, K., "Piąty dogmat?," in: idem (ed.), Tradycja i otwartość. Księga pamiątkowa ku czci O. prof. S.C. Napiórkowskiego, Lublin 1999, 81-99. 
Kudasiewicz, J., Mastalska, D., Biblijna droga pobożności maryjnej. $Z$ księdzem profesorem Józefem Kudasiewiczem rozmawia Danuta Mastalska, Kielce 2002.

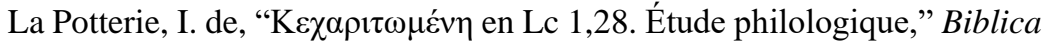
68 (1987), 357-382.


et théologique," Biblica 68 (1987), 480-508.

Langkammer, H., Dlaczego różańcowe Tajemnice Światta?: medytacje biblijne, Wrocław 2012.

Langkammer, H., Maryja w Nowym Testamencie, Gorzów Wielkopolski 1991.

Lemański, J., "JHWH - Bóg, który przebacza, gdyż jest miłosierny (Wj 34,5-7)," Verbum vitae 18 (2010), 19-43.

Lemmo, N., "Maria, 'Figlia di Sion' a partire di Lc 1,26-38: Bilancio esegetico dal 1939 al 1982," Marianum 45 (1983), 175-258.

Manelli, S.M., All generations shall call me Blessed: biblical mariology, New Bedford (MA) 1995.

Manelli, S.M., Mariologia biblica, Frigento 1989.

Most, W., "New Light on the Messianic-Marian Character of Isaiah 7:14," Miles Immaculatae 25 (1989) no. I-II, 54-67.

Neumann, C.W., "The Decline of Interest in Mariology as a Theological Problem," Marian Studies 23 (1972), 12-38.

Orygenes, Komentarz do Ewangelii wedtug Mateusza, K. Augustyniak (transl.), E. Stanula (ed.), Kraków 1998. = Origen, The commentary of Origen on the Gospel of St Matthew, R.E. Heine (intr., trans.), Oxford 2018.

Pennington, M.B., 20 tajemnic różańca: podróż biblijna, J. Ruszkowski (transl.), Poznań 2004. = Pennington, M.B., 20 Mysteries of the Rosary: A Scriptural Journey, Liguori (MO) 2003.

Pinckaers, S.T., Komentarz św. Augustyna do Kazania na górze, in: idem, Źródła moralności chrześcijańskiej, A. Kuryś (transl.), Poznań 1994.

Ratzinger, J. (Benedykt XVI), Balthasar, H.U. von, Maryja w tajemnicy Kościoła, W. Szymona (transl.), Kraków 2007. = Ratzinger, J., Balthasar, H.U. von, Mary, The Church at the Source, A. Walker (trans.), San Francisco (CA) 2005.

Ratzinger, J. (Benedict XVI), The Beatitudes are a new program of life, Angelus, Sunday, 30 January 2011, http://www.vatican.va/content/ benedict-xvi/en/angelus/2011/documents/hf_ben-Xvi_ang_20110130. html (access: 29.08.2020).

Ratzinger, J. (Benedykt XVI), Córa Syjonu: Maryja w refleksji Kościoła, B. Widła (transl.), Warszawa 1997. = Ratzinger, J. (Benedict XVI), 
Daughter Zion: Meditations on the Church's Marian Belief, San Francisco (CA) 1983.

Ratzinger, J. (Benedykt XVI), Jezus z Nazaretu, cz. 1, W. Szymona (transl.), Kraków 2007. = Ratzinger, J. (Benedict XVI), Jesus of Nazareth: From the Baptism in the Jordan to the Transfiguration, New York-London-etc. 2007.

Ratzinger, J. (Benedict XVI), Verbum Domini, http://www.vatican.va/ content/benedict-xvi/en/apost_exhortations/documents/hf_ben-xvi_ex h_20100930_verbum-domini.html (access: 29.08.2020).

Ratzinger, J. (Benedykt XVI), Wprowadzenie $w$ chrześcijaństwo, Z. Włodkowa (transl.), Kraków 1996. = Ratzinger, J. (Benedykt XVI), Introduction to Christianity, 2nd ed., San Francisco (CA) 2004.

Riches, A., "Deconstructing the Linearity of Grace: The Risk and Reflexive Paradox of Mary's Immaculate Fiat," International Journal of Systematic Theology 10 (2008) no. 2, 179-194.

Rinaldi, B., La Madonna nella fede tra le donne moderne. Per una rielaborazione della teologia femminile, Milano 1996.

Rondet, H., Maria nel disegno di Dio: Giuseppe l'uomo delle beatitudini, Roma 1966.

Rossé, G., "The mysteries of light," Living City 42 (2003) no. 5, 18-20.

Rossier, F., "Kecharitomene (Lk. 1:28) in the Light of Gen. 18:16-33: A Matter of Quantity," Marian Studies 55 (2004), 159-183.

Samiec, Ł., Maryja i "preferencyjna opcja na rzecz ubogich," Kraków 2019.

Seremak, J., "Paradygmat zbawczej obecności wyzwolenia: imię Boga Ehjeh-Jhwh, «Jestem-On jest» (Wj 3,14-15 / Wj 34,6-7)," Studia Bobolanum 29 (2018) no. 2, 141-161.

Serra, A.M., E c'era la Madre di Gesù... (Gv. 2,1): saggi di esegesi biblicomariana (1978-1988), Milano 1989.

Serra, A.M., "Poverty of Spirit and the «Marvelous Deeds» of God as Seen in Mary's Magnificat: Reflections from the Hebrew Scriptures," Marian Studies 50 (1999), 8-37.

Siwiński, N.M., "Rogamus te, Domina nostra - sześć modlitw maryjnych św. Antoniego z Padwy jako świadectwo mariologii franciszkańskiej XIII wieku," Collectanea Theologica 86 (2016) no. 3, 91-145.

Strong, J., Grecko-polski słownik Stronga z lokalizacją słów greckich $i$ kodami Popowskiego, A. Czwojdrak (transl.), Warszawa 2015. = Strong, J., A Concise Dictionary of the Words in the Hebrew Bible: With Their Renderings in the Authorized English Version, New York (NY) 1890. 
Stuhlmueller, C., "The Mother of Emmanuel (Is. 7:14)," Marian Studies 12 (1961), 165-204.

Swetnam J., "Hesed w Starym Testamencie a eleos w Nowym," Ruch Biblijny i Liturgiczny 51 (1998) no. 4, 251-260.

Szczepaniec, S., Rekolekcje „na różańcowym szlaku”: tajemnice światta, Kraków 2015.

Tischner, J., Ksiąieczka pielgrzyma, Warszawa 1996.

Tomasik, P., "Katecheza maryjna dzieci i młodzieży szkolnej. Źródła, zakresy tematyczne, zasady," Collectanea Theologica 89 (2019) no. 2, 159-182.

Van der Merwe, I.J., "Biblical happiness and baptismal identity," Stellenbosch Theological Journal 1 (2015) no. 2, 695-710.

Vereb, J., Pope John Paul II and the Luminous Mysteries of the Rosary, New Jersey (NJ) 2003.

Viviano, B.T., "Ewangelia według świętego Mateusza," in: R.E. Brown, J.A. Fitzmyer, R.E. Murphy (eds.), W. Chrostowski (ed. of the Polish edition), Katolicki Komentarz Biblijny, Warszawa 2018. = Viviano, B.T., "Gospel according to Matthew," in: R.E. Brown, J.A. Fitzmyer, R.E. Murphy (eds.), The New Jerome Biblical Commentary. Englewood Cliffs (NJ) 1990.

Wołowski, L., "Słowo o syntezie zasad Per Mariam ad Iesum i Per Iesum ad Mariam," Salvatoris Mater 77-80 (2018), 254-263.

Życiński, W., Matka, która pozostała Dziewica, Kraków 2017. 